\title{
Involvement of metabolic and insensitive acetylcholinesterase mechanisms in insecticide resistance of rice insect pests and predatory populations from Batalagoda, Sri Lanka
}

\author{
S.H.P.P. Karunaratne"and K.C. Weerakoon \\ Department of Zoology, University of Peradeniya, Peradeniya; Postgraduate Institute of Science, Peradentya.
}

Revised: 09 January 2007 ; Accepted: 16 March 2007

\begin{abstract}
Mechanisms of insecticide resistance were studied in five rice insect pests (brown planthopper Nilaparvata lugens; green leafhopper Nephotettix virescens; paddy bug Leptocorisa oratorius; white leafhopper Cofana spectra and white-backed planthopper Sogatella furcifera), and four of their predators (ladybird beetle Micraspis discolor; ground beetle Ophionea indica; mired bug Cytorhinus lividipennis and spider Tetragnatha sp.). Insects were collected from the rice fields at Batalagoda, Kurunegala, during $2001-2003$ and stored at $-20^{\circ} \mathrm{C}$
\end{abstract}

Biochemical assays were carried out within one week of storage to determine the activity levels of major enzyme groups (i.e carboxylesterases, glutathione S-transferases and monooxygenases), which are involved in insecticide metabolism. Native polyacrylamide gels were run with crude homogenates to resolve carboxylesterase isozymes. Sensitivity of the organophosphate and carbamate target site acetylcholineesterase was tested by inhibiting the enzyme with propoxur.

$N$. lugens, S. furcifera and $N$. virescens showed high insecticide resistance, especially to organophosphates and pyrethroids due to higher activity levels of metabolic enzymes. All the species were susceptible to malathion mainly because of the absence of malathion carboxylesterase mechanism. Resistance to permethrin in the populations of $N$. lugens, $C$. lividipennis, $M$. discolour, $O$. indica and Tetragnatha sp. may be due to their higher mono-oxygenase activities. Presence of insensitive acetylcholinesterases could be detected among the populations of N.lugens, C. spectra, C. lividipennis and Tetragnatha sp. It appears that multiple resistance mechanisms are present in the populations tested. Higher susceptibility levels of $L$. oratorius and $C$. spectra could be attributed to the absence of resistance mechanisms in these two species.

Key words: Insecticide resistance, insensitive acetylcholinesterase mechanisms, metabolic resistance, predatory insects, rice insect pests

\section{INTRODUCTION}

Continuous exposure to insecticides can lead to insecticide resistance in insect populations. When an insect population is exposed to an insecticide, it may also acquire resistance to other insecticides showing crossresistance. Development of insecticide resistance among pest populations forces the farmers to apply increased dosages of pesticides in order to obtain the same level of control as earlier. This over-use becomes a major threat to the environment and also selects highly resistant insect lines. An understanding of the biochemical mechanisms, which underlie insecticide resistance, is essential to delay or to prevent/ revert development of resistance and also to design new insecticides for resistant strains.

All four major groups of synthetic insecticides affect the nervous system of the insect and are therefore called 'neuro - inhibitors''. For organophosphates and carbamates, the target site is acetylcholinesterase (AChE), the enzyme that hydrolyses the neurotransmitter acetylcholine. Cyclodienes, a sub-group of organochlorines, bind to $\gamma$-aminobutyric acid (GABA) receptors in $\mathrm{Cl}^{-}$channels of neurons. Rest of the organochlorines (DDT and its analogues) and pyrethroids bind to $\mathrm{Na}^{+}$channel regulatory proteins of the nerve membrane inactivating their regulation. There are two major resistance mechanisms developed by insects to insecticides; metabolic resistance and altered target site resistance.

Metabolic resistance is the most common mechanism of insecticide resistance. Insects use their enzyme systems,

\footnotetext{
"Corresponding author
} 
to metabolize insecticides before the insecticides reach their target site. These enzymes belong to three major groups; carboxylesterases (CEs), glutathione S-transferases (GSTs) and mono-oxygenases (mixed-function oxidases- MFOs). Metabolic resistance results from either qualitative or quantitative changes of these enzymes. Increased number of copies of the gene/s coding for an enzyme, over expression of the gene/s or increased mRNA stability may be the cause for quantitative changes of the enzymes. Qualitative changes may be due to gene mutations so that the resulting enzyme has a higher catalytic centre activity towards insecticides ${ }^{2}$.

In altered target site (insensitive targetsite) mechanism, the target site of an insecticide is altered so that the insecticide molecules cannot interact with it. Alteration of a target site is highly specific because the altered target site still has to carry out its normal physiological functions inside the insect body. Most of these changes occur due to a substitution of a single amino acid in the protein sequence of the target site ${ }^{1}$.

This study was designed to identify some of the underlying biochemical mechanisms of resistance in rice insect pest and predatory insect populations in a selected rice growing area in Sri Lanka. Cross-resistance spectra of these insect populations have already been studied ${ }^{3}$

\section{METHODS AND MATERIALS}

Study site and insects: Rice insect pests and predatory insects were collected during 2001 to 2003 from an irrigated rice field at Batalagoda $\left(7^{0} 30 \mathrm{~N}\right.$ and $80^{\circ} 20^{\circ} \mathrm{E}, 100 \mathrm{~m}$ above the sea level), Kurunegala district, located in the Intermediate zone of Sri Lanka.

Adults of five species of rice insect pests, namely Nilaparvata lugens (Homoptera: Delphacidae), Leptocorisa oratorius (Heteroptera: Alydidae), Nephotettix virescens (Homoptera: Cicadellidae), Sogatella furcifera (Homoptera: Delphacidae) and Cofana spectra (Homoptera: Cicadellidae); and four species of their insect predators, namely Micraspis discolor (Coleoptera: Coccinellidae), Ophionea indica (Coleoptera: Carabidae), Tetragnatha sp. (Aranea: Tetragnathidae) and Cytorhinus lividipennis (Homoptera: Miridae) were collected from the rice fields using sweepnet and blower-vac methods, brought live to the laboratory of the Department of Zoology, University of Peradeniya and stored at $-20^{\circ} \mathrm{C}$. Biochemical assays were carried out within one week of storage.

Chemicals and equipment: Chemicals were purchased from Sigma, USA. unless otherwise stated. Paraoxon ( $98 \%$ pure) was from Greyhound, UK; malathion ( $97.5 \%$ pure) was a gift from Cheminova, Denmark; propoxur $(98.5 \%$ pure) was from Bayer, Germany and permethrin ( $98 \%$ pure) was from Aventis, UK. Microcentrifuge was purchased from the SANYO Company, UK. and miniprotean $11 \mathrm{gel}$ electrophoresis was from BIO-RAD, UK. UV max $_{\text {kinetic }}$ plate reader and $\mathrm{KC}_{3}$ computer software were from Molecular Devices, Bio-Tek, USA.

\section{Biochemical experiments:}

Microtitre plate assays: Two hundred individuals from specific pest and predatory species were used for each microtitre plate assay. Insects were individually homogenized in 100-120 $\mu \mathrm{L}$ (depending on the size of the species) of ice-cold distilled water. Homogenates were centrifuged at $13,000 \mathrm{~g}$ for $2 \mathrm{~min}$ and the supernatants were used for assays.

Carboxylesterase assay: A stock solution of $100 \mathrm{mM}$ p-nitrophenyl acetate (pNPA) was prepared in acetone. $1 \mathrm{mM}$ working solution of pNPA was prepared immediately before each experiment with $50 \mathrm{mM}$ phosphate buffer $\mathrm{pH}$ 7.4. $10 \mu \mathrm{L}$ of the insect homogenate was mixed with $200 \mu \mathrm{L}$ of the working solution in separate microtitre plate wells and the reaction was read immediately at $12 \mathrm{~s}$ intervals at $405 \mathrm{~nm}$ for $2 \mathrm{~min}$ at $21^{\circ} \mathrm{C}$. An extinction coefficient $(\varepsilon)$ of $6.53 \mathrm{mM}^{-1}$ (correlated for the path length of $0.6 \mathrm{~cm}$ for $210 \mu \mathrm{L}$ ) was used to convert the absorbance values to moles ${ }^{4}$.

Glutathione S-transferase (GST) assay: $10 \mathrm{mM}$ reduced glutathione (GSH) in $0.1 \mathrm{M}$ phosphate buffer $\mathrm{pH} 6.5$ and $63 \mathrm{mM}$ 1-chloro-2,4-dinitro benzene (CDNB) in methanol were mixed together to prepare the working solution. Each insect homogenate $(10 \mu \mathrm{L})$ was mixed with $200 \mu \mathrm{L}$ of GSH/ CDNB working solution in a microtitre plate well. The plate was read at $340 \mathrm{~nm}$ at 12 intervals for $5 \mathrm{~min}$. An extinction co-efficiant of 5.76 (corrected for the path length of $0.6 \mathrm{~cm}$ for $210 \mu \mathrm{L}$ ) was used to convert the absorbance values to moles 5 .

Mono-oxygenase assay: Twenty microlitres $(20 \mu \mathrm{L})$ of each insect homogenate was mixed with $80 \mu \mathrm{L}$ of potassium phosphate buffer $\mathrm{pH} 7.2+200 \mu \mathrm{L}$ of $6.3 \mathrm{mM}$ tetramethyl benzidine (TMBZ) working solution $(0.01 \mathrm{~g}$ TMBZ dissolved in $5 \mathrm{~mL}$ methanol and then in $15 \mathrm{~mL}$ of sodium acetate buffer $\mathrm{pH} 5.0)+25 \mu \mathrm{L}$ of $3 \% \mathrm{H}_{2} \mathrm{O}_{2}$ solution in a microtitre plate well. After two hours of incubation at $26^{\circ} \mathrm{C}$, the plate was read at $630 \mathrm{~nm}$ as an end point assay ${ }^{6}$. This assay does not measure mono-oxygenase activity but titrates the amount of haem in the insect homogenate. Since haem is present in the active site of monooxygenases, the amount of haem corresponds to the 
amount of oxidase present. By using a standard curve of cytochrome $\mathrm{C}$, an estimate of the amount of the oxidase present was obtained and expressed as equivalent units of cytochrome $\mathrm{P}^{450}$.

Protein assay: To obtain specific activities of enzymes, protein concentrations of the homogenates were determined using a BIO-RAD protein determination kit, with bovine serum albumin as the standard protein. $10 \mu \mathrm{l}$ of homogenate was mixed with $300 \mu \mathrm{l}$ of BIO-RAD working solution (prepared according to the instructions of the manufacturer) and the absorbance was read at $630 \mathrm{~nm}$ as an end point assay after a five-minute incubation at room temperature.

Malathion metabolism: Batches of each insect species $(50-700 \mathrm{mg}$ wet weight $=25$ individuals $)$ were homogenized in $0.5 \mathrm{~mL}$ of $25 \mathrm{mM}$ Tris-HCl buffer (pH 7.5) and centrifuged at $13,000 \mathrm{~g}$ for $5 \mathrm{~min}$. Supernatant was incubated with $300 \mu \mathrm{M}$ malathion for $2 \mathrm{~h}$ at room temperature. The mixture was then extracted twice with $0.5 \mathrm{~mL}$ acidified chloroform. The chloroform extract was dried under a current of air, redissolved in $30 \mu \mathrm{L}$ acidified chloroform and loaded onto a thin layer chromatography plate. After running with n-hexane: diethyl ether (1:3) the plate was sprayed with $0.5 \%$ (w/v) 2,6-dibromoquinone 4-chloromide in cyclohexane and left at $100^{\circ} \mathrm{C}$ for $2 \mathrm{~h}$ to visualize malathion and its metabolic products. Buffer $(0.5$ $\mathrm{mL}$ ), incubated with $300 \mu \mathrm{M}$ malathion and $300 \mu \mathrm{M} \mathrm{NaOH}$ was run as a positive control. Buffer $(0.5 \mathrm{ml})$, incubated with the same concentration of malathion, was run as a negative control ${ }^{7}$.

Acetylcholinesterase (AChE) assay: The insect homogenate $(2 \times 20 \mu \mathrm{L}$ aliquots $)$ was added to two consecutive microtiter plate wells, each containing 145 $\mu \mathrm{L}$ of $1 \%$ Triton X-100 in $0.1 \mathrm{M}$ sodium phosphate buffer $(\mathrm{pH} 7.8)$ and $10 \mu \mathrm{l}$ of dithiobis-2-nitrobenzoic acid in phosphate buffer ( $\mathrm{pH} 7.0$ ). To one set of homogenates, $25 \mu \mathrm{L}$ of acetylthiocholine iodide (ASChI) and $10 \mu \mathrm{L}$ of $0.1 \mathrm{M}$ propoxur solution $(2.5 \mathrm{~mL} 0.1 \mathrm{M} \mathrm{ASChI}+10 \mu \mathrm{L}$ of $0.1 \mathrm{M}$ propoxur in acetone) were added. To other replicate, $25 \mu \mathrm{L}$ of ASChI alone was added. The plate was read at $405 \mathrm{~nm}$ for $5 \mathrm{~min}$. Results were expressed as the percentage remaining activity in the inhibited fraction compared with the control (uninhibited) activity ${ }^{8}$.

Polyacrylamide gel electrophoresis (PAGE): Native polyacrylamide gel electrophoresis (PAGE) was used to visualize elevated esterase isozymes. Mass homogenates of 5-25 individuals (equivalent to $50 \mathrm{mg}$ ) of each insect species were homogenized in $250 \mu \mathrm{L}$ of $50 \mathrm{mM}$ sodium phosphate buffer $\mathrm{pH} 7.4$. Electrophoresis of $10,000 \mathrm{~g}$ supernatants from crude homogenates was performed in
$7.5 \%$ acrylamide gels in tris/borate buffer $\mathrm{pH} 8.0$ containing $0.2 \mathrm{mM}$ Ethylenediamine tetra-aceic acid (EDTA). Gels were stained for esterase activity with $0.04 \%$ $(w / v) \alpha$-and $\beta$-naphthyl acetate and $0.1 \%(w / v)$ Fast Blue $B$ in $100 \mathrm{mM}$ phosphate buffer $\mathrm{pH} 7.4$ and the elevated esterases appears as purple ( $\alpha$ - naphthyl acetate preferred) or pink ( $\beta$ - naphthyl acetate preferred) bands. Rate of flow $\left(R_{t}\right)=$ Distance to the band from the bottom of the well / Distance to the dye front from the well.

For insecticide inhibition studies, gels were incubated separately with $0.1 \mathrm{mM}$ paraoxon, propoxur and permethrin in phosphate buffer (pH 7.2) after electrophoresis for $10 \mathrm{~min}$, and then exposed to the substrate solutions. Control experiments were done by incubating with buffer without insecticides. The degree of inhibition of each band was recorded according to their colour intensity compared with the control.

\section{RESULTS}

Activity profiles (percentage population $v s$ specific activity) for carboxylesterases and GSTs and quantity profiles for mono-oxygenases were obtained for all nine populations of pest and predatory insects. Percentages of insect populations which show more than $0.15 \mu \mathrm{mol} /$ $\mathrm{mg} / \mathrm{min}$ carboxylesterase activity, $0.4 \mu \mathrm{mol} / \mathrm{mg} / \mathrm{min}$ GST activity and 3 equivalent units of Mono-oxygenase amounts are presented in the Figure 1. These discriminating values were decided after examining all the activity profiles.

The highest activity of carboxylesterases for the substrate p-nitrophenyl acetate was seen in S. furcifera $(1.91 \pm 1.39 \mu \mathrm{mol} / \mathrm{min} / \mathrm{mg}$ mean activity) and the lowest activity was seen in $L$. oratorius $(0.02 \pm 0.04 \mu \mathrm{mol} / \mathrm{min} /$ mg mean activity). Highest GST activities were seen in the predator $M$. discolor $(0.50 \pm 0.35 \mu \mathrm{mol} / \mathrm{min} / \mathrm{mg}$ mean value) and the lowest activity was in the predator Tetragnatha sp. $(0.11 \pm 0.11 \mu \mathrm{mol} / \mathrm{min} / \mathrm{mg}$ mean value $)$. High mono-oxygenase concentrations were present in two predators, $M$. discolor $(3.82 \pm 5.17$ units $)$ and Tetragnatha sp. $(8.75 \pm 11.85$ units $)$ and others had moderate activities.

Native polyacrylamide gel electrophoresis (PAGE) showed elevated esterase bands in all the species except $O$. indica (Figure 2). Activity of all the isoenzyme bands was completely inhibited by paraoxon, partially inhibited by propoxur and not inhibited by permethrin.

Thin layer chromatography analysis showed that the carboxylesterase mechanism was not present in any of the rice insect pests and predators tested. The 

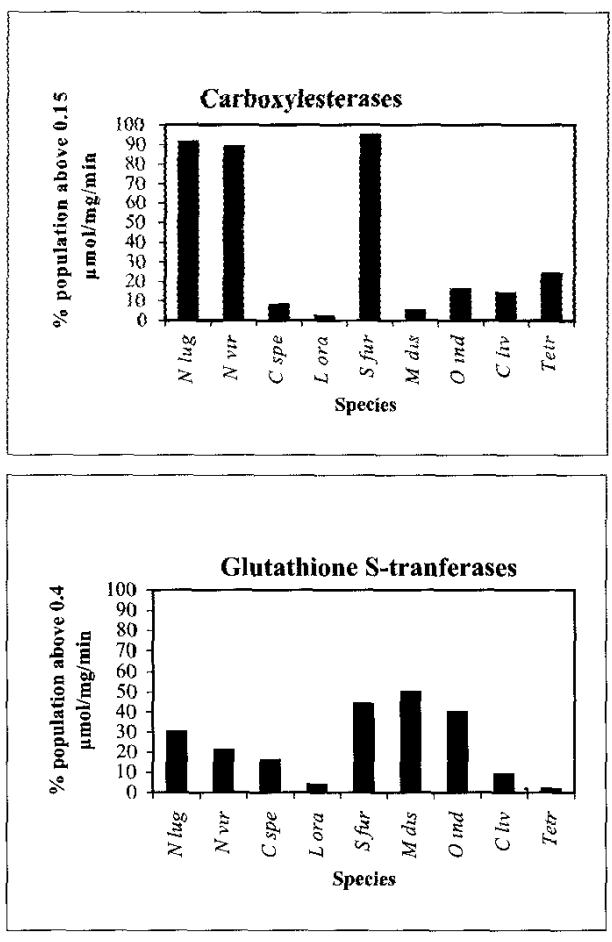

\begin{tabular}{|l|}
\hline \multicolumn{1}{|c|}{ Species } \\
N.lug-N.lugens \\
N.vir-N.virescens \\
C.spe-C.spectra \\
L.ora-L.oratorius \\
S.fur-S.furcifera \\
M.dis-M.discolor \\
O.ind-O.indica \\
C.liv-C.lividipennis \\
Tetr-Tetragnatha sp.
\end{tabular}

Figure 1: Percentages of insect populations which show more than $0.15 \mu \mathrm{mol} / \mathrm{mg} / \mathrm{min}$ carboxylesterase activity, 0.4 $\mu \mathrm{mol} / \mathrm{mg} / \mathrm{min}$ GST activity and 3 equivalent units of mono-oxygenase amounts $(\mathrm{n}=200$ for each population for each assay, discriminating values were decided after examining all the activity profiles.).

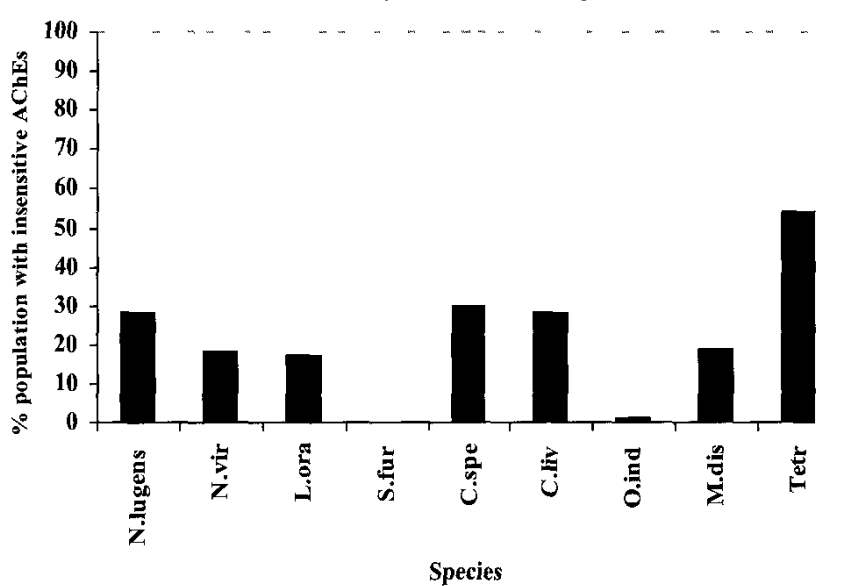

Figure 2: Percentages of insect populations which showed more than $70 \%$ remaining activity of acetylcholinesterases (insensitive AChEs) after inhibition with propoxur $(n=200$ for each population) homogenates of the pests and predators could not metabolize malathion within the standard time period and the monoacid and diacid products were not present on the TLC plate.

Remaining activity profiles were obtained for propoxur- AChE inhibition assay. More than 70\% remaining activity of $\mathrm{AChEs}$, after inhibition by a standard dosage of propoxur, was observed in $28 \%$ of $N$. lugens, $18 \% N$. virescens, $30 \%$ C. spectra, $17 \%$ L. oratorius, $0 \%$ $S$ : furcifera, $19 \%$ M.discolor, $1 \%$ O. indica, $28 \%$ C. lividipennis and 54\% Tetragnatha sp. populations (Figure 3).Presence and absence of the studied mechanisms in each insect population are summarised in Table 1. 
Table 1: Presence/absence of resıstance mechanisms in differcnt insect populations

\begin{tabular}{|l|c|c|c|c|c|}
\hline \multicolumn{1}{|c|}{ Species } & CE & MCE & GST & Ox & AChE \\
\hline N lugens & +++ & & ++ & ++ & ++ \\
\hline S furtifera & +++ & - & ++ & & - \\
\hline N verescen & +++ & - & - & - & - \\
\hline C spectra & & - & & & ++ \\
\hline L oratorus & - & - & - & - & - \\
\hline Clundpenmis & ++ & - & - & ++ & ++ \\
\hline M discolor & - & & +++ & ++ & \\
\hline O lndica & - & - & ++ & ++ & - \\
\hline Tetragnatha sp & ++ & - & - & +++ & ++ \\
\hline
\end{tabular}

\section{DISCUSSION}

Elevated caboxylesterases of insects are well known for providing organophosphate and carbamate resistance to insects ${ }^{9-13}$. They can rapidly bind to the insecticides but the release of the free enzyme is much slower ${ }^{4,9}$. Mean carboxylesterase activity range (with the substrate p-nitrophenyl acetate) obtained in the present study was $1.91 \pm 1.39$ to $0.02 \pm 0.04 \mu \mathrm{mol} / \mathrm{min} / \mathrm{mg}$. Specific activity values have not been reported previously for these species. However, these data can be compared with the data (obtained for the same substrates), which have been reported for some other Sri Lankan insects previously i.e. $0.40 \pm 0.64$ and $0.70 \pm 0.46 \mu \mathrm{mol} / \mathrm{min} / \mathrm{mg}$ for the cockroaches Periplaneta americana and $P$. australasia respectively ${ }^{14}$, $0.39 \pm 0.34,0.23 \pm 0.19$ and $0.17 \pm 0.23 \mu \mathrm{mol} / \mathrm{min} / \mathrm{mg}$ for the mosquitoes Anopheles culicifacies, An. subpictus and Culex tritaeniorynchus respectively ${ }^{15}{ }^{16}$. For some of the vegetable insect pests, mean carboxylesterase specific activity ranged from $1.01 \pm 0.65$ to $0.20 \pm 0.15 \mu \mathrm{mol} / \mathrm{min} /$ $\mathrm{mg}^{17}$. Therefore, the rice insect pests $S$. furcifera $(1.91 \pm$ $1.39 \mu \mathrm{mol} / \mathrm{min} / \mathrm{mg}), N$. lugens $(0.77 \pm 0.57 \mu \mathrm{mol} / \mathrm{min} / \mathrm{mg})$ and $N$. virescens $(1.13 \pm 0.78 \mu \mathrm{mol} / \mathrm{min} / \mathrm{mg})$ show comparatively higher carboxylesterase activity levels. The lowest activity $(0.02 \pm 0.19 \mu \mathrm{mol} / \mathrm{min} / \mathrm{mg})$ for pNPA substrate had been previously recorded for a susceptible population of the mosquito Culex quinquefasciatus ${ }^{18}$. The paddy bug $L$. oratorius population also had such a low level of carboxylesterase activity $(0.02 \pm 0.04 \mu \mathrm{mol} / \mathrm{min} /$ $\mathrm{mg})$. In the present study all the insect species tested showed $\beta$-naphtyl acetate specific bands except $O$. indica. Insecticide inhibition of esterase bands confirmed that the carboxylesterases present in the rice insects studied mainly react with organophophates and to a lesser extent with carbamates, and are capable of causing resistance to these two insecticide groups.

The malathion carboxylesterase assay measures the activity of altered carboxylesterases. Unlike elevated carboxylesterases, which give resistance to a wide range of organophosphates and carbamates, malathion carboxylesterases have only a very narrow cross resistance spectrum and provide resistance specifically to malathion ${ }^{1}$. This mechanism has been reported from Sri Lankan populations of the mosquito An. culicifacies and $A n$. subpictus ${ }^{15}$ and the vegetable pest insects $M$. persicae, $P$. xylostella and $L$. huidobrensis and Callosobruchus maculatus ${ }^{17,19}$. Absence of this mechanism in rice insect pests may indicate less exposurc of rice insects to the insecticides used by health sector such as malathion which has been heavily used in mosquito control since 1975 .

Mean GST activities of rice insect populations ranged from $0.55 \pm 0.57$ to $0.11 \pm 0.11 \mu \mathrm{mol} / \mathrm{min} / \mathrm{mg}$. For cockroaches Periplaneta americana and $P$. australasia, the mean values were $0.78 \pm 0.62$ and $0.65 \pm 0.28 \mu \mathrm{mol} /$ $\mathrm{min} / \mathrm{mg}$ respectively ${ }^{15}$. For the mosquitoes $A n$. culicifacies, $A n$. subpictus and C. tritaeniorynchus, the mean values were $0.24 \pm 0.14,0.30 \pm 0.24$ and $0.35 \pm$ $0.33 \mu \mathrm{mol} / \mathrm{min} / \mathrm{mg}$ respectively ${ }^{15,16}$. For some of the vegetable insect pests the GST activity range was from $1.43 \pm 1.24$ to $0.34 \pm 0.27 \mu \mathrm{mol} / \mathrm{min} / \mathrm{mg}^{17}$. Mean monooxygenase concentration of rice insect pests ranged from $8.75 \pm 11.85$ to $0.87 \pm 1.25$ units. Some of the vegetable insect pests have shown a range of $1.08 \pm 1.75$ to $67.81 \pm$ 787.90 units of mono-oxygenase concentrations with the same assaying systems ${ }^{17}$. Based on these results it can be concluded that N.lugens, S. furcifera, M.discolor and $O$. indica have high GST activities and N.lugens, M.discolor, $O$. indica, C. lividipennis and Tetragnatha sp. have high mono-oxygenase levels (Table 1).

Acetylcholinesterase is the target site of organophosphates and carbamates. Measuring the residual activity of acetylcholinesterases after interacting with propoxure can assess insensitivity of the target site. Results can be expressed as the percentage residual activity in the inhibited fraction compared with the activity in the control fraction of the same insect. Residual activity of more than $70 \%$ indicates the presence of an altered AChE in Anopheles and Culex mosquitoes ${ }^{20}$. Accordingly, this mechanism can be clearly seen among the populations of N.lugens, C. spectra, C. lividipennis and Tetragnatha sp. (Table 1).

$N$. lugens, S. furcifera and $N$. virescens has shown high insecticide resistance, especially to organophosphates and pyrethroids ${ }^{3}$. This must be due to their higher activity levels of metabolic enzymes as indicated by the present work. Absence of malathion carboxylesterases is in accordance with high susceptibility to malathion observed in all nine mosquito populations ${ }^{1}$ Resistance to permethrin in Batalagoda populations of $N$. lugens, C. lividipennis, $M$. discolor, $O$. indica and 
Tetragnatha $\mathrm{sp}^{1}$ may be due to therr higher monooxygenase activities Resistance of $S$ furcifera is mainly due to both carboxylesterases and glutathone S-transferases and that of $N$ virescens is due to carboxylesterases In general, it appears that more than one mechanism is involved in insecticide resistance of rice insect pests Higher susceptibility levels of $L$ oratorius and $C$ spectra ${ }^{3}$ can be attributed to the absence of resistance mechanisms in these two species

\section{Acknowledgement}

This work was funded by the National Science Foundation of Sr1 Lanka Research Grant No RG/99/B/01

\section{References}

1 Karunaratne S H P P (1998) Insecticide cross-resistance in insects A Review Ceyıon Journal of Biological Sctence 25 72-82

2 Hemingway J , Hawkes $\mathrm{N}$ J , McCarroll L \& Ranson $\mathrm{H}$ (2004) The molecular basis of insecticide resistance in mosquitoes Insect Biochemistry and Molecular Bıology 34653665

3 Karunaratne S H P P, Weerakoon K C , Nugaliyadda L \& Manuweera GK (2006) Susceptibility of rice insect pests and their natural enemies to commonly used insecticides Journal of the National Sctence Counctl of Srl Lanka (in print)

4 Karunaratne S H P P, Jayawardena K G I , Hemingway J \& Ketterman A J (1993) Characterisation of a B type esterase involved in insecticide resistance from the mosquito Culex quinquifaciatus Blochemical Journal 294 575-579

5 Brogdon W G \& Barber A M (1990) Microplate assay of glutathione-S-transferase activity for resistance detection in single mosquito tritrates Comparative Biochemistry and Physiology 96 339-342

6 Brogdon W G, McAllıster J C \& Vulule J M (1998) Heam peroxidase activity measured in single mosquitoes identifies individual expression of an elevated oxidase for insecticide resistance Journal of American Mosquito Association 13 233-237

7 Karunaratne S H P P \& Hemıngway J (2001) Malathın resistance and prevalence of the malathion carboxylesterase mechanısm in populations of Srı Lankan mosquito vectors of disease Bulletin of the World Health Organization 79(11) 1060-1064

8 Moores GD, Devonshire A L \& Denholm I (1988) A microtitre plate assay for characterizing insensitive acetylcholinesterase genotypes of insecticide resistant insects Bulletin of Entomological Research $78537-544$

9 Devonshire A L \& Moores R D (1982) Acarboxylesterase with broad substrate specificity causes organophosphrous, carbamate and pyrethroid resistance in peach-potato aphids (Myzus persicae) Pestucide Biochemistry and Physiology 18235246

10 Ketterman A J, Jayawardena K G I \& Hemingway J (1992) Purfication and characterization of carboxylesterase involved in insecticide resistance from the mosquito Culex quinquefasciatus Biochemical Journal 287355360

11 Ketterman A J, Karunaratne S H P P, Jayawardend K G I \& Hemingway J (1993) Qualitative differences between populations of Culex quinquefaciatus in both the esterases $A_{2}$ and $B_{2}$, which are involved in insecticide resistance Pestucide Blochemistry and Physiology 47 142148

12 Karunaratne S H P P, Small G J \& Hemungway J (1999) Characterization of the elevated esterase- associated insecticide resistance mechanism in Nilaparvata lugens (Stal) and other planthopper species International Journal of Pest Management 45(3) 225-230

13 Hemingway J, Karunaratne S H P P \& Clarıdge M F (1999) Insecticide resistance spectra and underlying resistance mechanisms in tropical populations of the brown planthopper (Nilaparvata lugens) collected from rice and the wild grass Leersia hexandra International Journal of Pest Management 45(3) 215-223

14 Karunaratne S H P P (1999b) Possible mechanisms of insecticide tolerance in the cockroaches Periplaneta americana (L) and $P$ australia (F) Ceylon Journal of Biological Science 27(1) 9-18

15 Karunaratne S H P P (1999a) Insecticide cross resistance mechanisms of Sri Lankan Anopheline vectors of maları Southeast Asian Journal of Tropical Medicıne and Publıc Health 30(3) 460-469

16 Karunaratne S H P P \& Hemingway J (2000) Insecticide resistance spectra and mechanisms in population of Japanese encephalitis vector mosquitoes, Culex tritaeniorhynchus and Culex gelıdus, in Sri Lanka Medical and Veterinary Entomology 14 430-436

17 Damayanthı B T \& Karunaratne S H P P (2005) Biochemical characterisation of insecticide resistance in vegetable insect pests and predatory ladybird beetles Journal of the National Science Councl of Sri Lanka 33(2) 115-122

18 Karunaratne S H P P, Hemıngway J , Jaydwardana K G J \& Vaughan A (1995) Kinetic and molecular differences in the amplified and non-amplified esterses from insecticide resistance and susceptible Culex quinquefasciatus mosquitoes Journal of Blological Chemistry 270: 31124 31128

19 Bogamuwa M M S , Weerakoon K C \& Karunaratne S H P P (2002) Insecticide resistance in the Bruchid Callosobruchus maculatus, a storage pest of legumes Ceylon Journal of Bıologıcal Science 30 55-66

20 World Health Organization (1998) Techntques to detect insecticude resistance mechanisms (field and laboratory manual), p 35 WHO, Geneva, Switzerland 